\title{
PENINGKATAN AKTIVITAS BELAJAR AKUNTANSI MELALUI MODEL PEMBELAJARAN TIPE THINK PAIR SHARE BERBANTUAN MEDIA MODUL
}

\section{INCREASED LEARNING ACTIVITY OF ACCOUNTING THROUGH LEARNING MODEL TYPE THINK PAIR SHARE ASSISTED MEDIA MODULE}

\author{
Oleh: \\ Septi Wuri Handayani \\ Mahasiswa Pendidikan Akuntansi Universitas Negeri Yogyakarta \\ anda_potter@yahoo.com
}

\begin{abstract}
Abstrak
Penelitian ini adalah Penelitian Tindakan Kelas yang bertujuan untuk meningkatkan Aktivitas Belajar Akuntansi siswa kelas X Akuntansi 1 SMK YAPEMDA 1 Sleman tahun ajaran 2013/2014 melalui Model Pembelajaran Kooperatif Tipe Think Pair Share Berbantuan Media Modul dan mengetahui respon siswa terhadap model pembelajaran. Penelitian ini dilaksanakan dalam bentuk kolaboratif yang dilaksanakan dalam dua siklus. Teknik pengumpulan data dalam penelitian ini melalui observasi, angket, catatan lapangan dan dokumentasi. Analisis data yang digunakan adalah analisis kualitatif dan analisis kuantitatif. Berdasarkan hasil penelitian disimpulkan bahwa Penerapan Model Pembelajaran Kooperatif Tipe Think Pair Share Berbantuan Media Modul dapat meningkatkan Aktivitas Belajar Akuntansi siswa kelas X Akuntansi 1 SMK YAPEMDA 1 Sleman Tahun Ajaran 2013/2014 yang dibuktikan dengan adanya peningkatan Aktivitas Belajar Akuntansi sebesar 10,83\% yaitu $74,17 \%$ pada siklus I dan meningkat menjadi $85,00 \%$ pada siklus II. Peningkatan Aktivitas Belajar Akuntansi didukung dengan adanya respon positif dari siswa yaitu pada siklus I mendapat respon sebesar $77,18 \%$ dan meningkat menjadi $79,62 \%$ pada siklus II.
\end{abstract}

Kata kunci : Aktivitas Belajar, Think Pair Share (TPS), Modul

\begin{abstract}
This research is Classroom Action Research which aims to improve student Learning Activity of Accounting class X Akuntansi 1 SMK YAPEMDA 1 Sleman academic year 2013/2014 through the Implementation of Cooperative Learning Model Type Think Pair Share with Media Assisted Learning Module and to know students response about thats learning model. This research was conducted in two cycles of collaborative form. The technique of collecting data in this research was conducted by observation, questionnaire and dokumentation. Analysis of the data used is the qualitative analysis and quantitative analysis. Based on the result of the research, it can be concluded that Cooperative Learning Model Type Think Pair Share with Media Assisted Learning Module can improve student Learning Activity of Accounting class X Akuntansi 1 SMK YAPEMDA 1 Sleman academic year 2013/2014 as evidenced by an increase in student Learning Activity of Accounting for $10.83 \%$ that is $74.17 \%$ in the first cycle and increased to $85.00 \%$ in the second cycle. Increased Learning Activity of Accounting is supported by the positive response from the students that got a response in the first cycle by $77.18 \%$ and increased to $79.62 \%$ in the second cycle
\end{abstract}

Keyword: Learning Activity, Think Pair Share, Module 


\section{PENDAHULUAN}

Pendidikan merupakan instrumen penting dalam meningkatkan kualitas sumber daya manusia. Pendidikan dipandang sebagai cara yang tepat untuk menciptakan sumber daya manusia yang berkualitas, karena melalui pendidikan manusia mendapatkan pengetahuan, keterampilan, keahlian dan nilai-nilai sikap. Pendidikan membuat manusia untuk berpikir sistematis, rasional dan bersikap kritis terhadap masalah-masalah pada era globalisasi. Pendidikan merupakan salah satu fondasi bangsa untuk menghasilkan generasi yang cakap dalam segala hal untuk bisa bersaing di era globalisasi. Dengan kata lain diperlukan sumber daya manusia yang berkualitas dan tangguh, serta peka terhadap perubahan dan pembaharuan sehingga mampu bersaing di era globalisasi seperti saat ini.

Menurut Aip Syarifudin dalam Arif Rohman (2009:8) pendidikan adalah proses yang dirancang dan disusun secara sistematis untuk merangsang pertumbuhan, perkembangan, meningkatkan kemampuan dan keterampilan, kecerdasan dan pembentukan watak, serta nilai dan sikap yang positif bagi setiap warga negara dalam rangka mencapai tujuan pendidikan.

Cara untuk mencapai tujuan pendidikan nasional adalah dengan memperbaiki kualitas proses belajar dan proses pembelajaran seperti dalam definisi pendidikan yang tercantum dalam Undangundang Nomor 20 Tahun 2003 tentang Sistem Pendidikan Nasional. Proses belajar dan proses pembelajaran yang baik akan menjadikan hasil belajar dapat lebih maksimal yang mengembangkan potensi masing-masing peserta didik, sehingga proses belajar dan proses pembelajaran menjadi hal yang sangat penting untuk diperhatikan karena merupakan salah satu penentu keberhasilan pendidikan.

Salah satu hal yang sangat penting dalam proses pendidikan atau pembelajaran, yaitu metode pendidikan atau metode mengajar. Metode pembelajaran merupakan cara praktis yang dipakai pendidik untuk menyampaikan materi pendidikan agar bisa efektif dan efisien diterima oleh peserta didik (Arif Rohman, 2009: 180). Dalam praktik pembelajaran di kelas guru harus memilih strategi pembelajaran yang dianggap paling tepat. Strategi yang dipilih disesuaikan dengan hakikat pembelajaran, karakteristik peserta didik, jenis materi pembelajaran, situasi dan kondisi lingkungan, dan tujuan yang akan dicapai.

Saat ini para pakar dunia pendidikan sudah banyak yang mengembangkan model pembelajaran yang berorientasi pada siswa. Model pembelajaran yang mengacu kepada kemampuan dan perkembangan belajar siswa, seperti model pembelajaran kooperatif, model pembelajaran kolaboratif, model pembelajaran inkuiri, model pembelajaran kontekstual dan model pembelajaran lainnya. Salah satu model pembelajaran kelompok adalah model pembelajaran kooperatif (cooperative learning) yang akhir-akhir ini menjadi perhatian dan dianjurkan para ahli pendidikan untuk digunakan (Wina Sanjaya, 2006: 242). Menurut Slavin (1995) dalam Wina Sanjaya (2006: 242) mengemukakan dua alasan menggunakan strategi pembelajaran kooperatif, pertama beberapa hasil penelitian membuktikan bahwa penggunaan pembelajaran kooperatif dapat meningkatkan prestasi belajar siswa sekaligus meningkatkan kemampuan hubungan sosial, menumbuhkan sikap menerima kekurangan diri dan orang lain serta dapat meningkatkan harga diri. Kedua, pembelajaran kooperatif dapat merealisasikan kebutuhan siswa dalam belajar berpikir, memecahkan masalah dan mengintegrasikan pengetahuan dengan keterampilan. Dari dua alasan tersebut, maka pembelajaran kooperatif merupakan bentuk pembelajaran yang dapat memperbaiki sistem pembelajaran yang selama ini memiliki banyak kelemahan. 
Pembelajaran kooperatif merupakan suatu sikap atau perilaku bersama dalam bekerja atau membantu di antara sesama dalam struktur organisasi yang teratur dalam kelompok, yang terdiri dari dua orang atau lebih dimana keberhasilan kerja sangat dipengaruhi oleh keterlibatan dari setiap anggota kelompok itu sendiri (Etin Solihatin dan Raharjo, 2007:4). Pembelajaran kooperatif memiliki banyak tipe, salah satu tipe yang menekankan kemampuan siswa untuk membangun pengetahuan dan kemampuan berpikir yang menuntut siswa untuk ikut aktif dalam proses pembelajaran di kelas adalah model pembelajaran kooperatif tipe Think Pair Share. Penerapan model pembelajaran kooperatif tipe Think Pair Share terdiri dari tiga langkah, pertama thinking (berfikir) yaitu guru mengajukan pertanyaan atau isu yang berhubungan dengan pelajaran, selanjutnya siswa diminta untuk memikirkan jawaban dan menghimpun informasi mengenai pertanyaan tersebut. Kedua, pairing (berkelompok) yaitu guru meminta siswa untuk berkelompok dan kemudian mendiskusikan hasil pemikiran mereka. Ketiga, sharing (berbagi pengalaman) yaitu guru meminta kelompok untuk berbagi kepada seluruh kelas tentang apa yang telah didiskusikan.

Selain menentukan strategi pembelajaran yang sesuai, guru juga perlu memperhatikan materi pembelajaran atau bahan ajar yang disampaikan kepada peserta didik. Materi pembelajaran yang disampaikan harus sesuai dengan kurikulum yang berlaku. Kurikulum berperan sabagai rencana pembelajaran, karena merupakan suatu program pendidikan yang disediakan untuk membelajarkan siswa sehingga dapat mencapai tujuan pembelajaran yang telah direncanakan. Salah satu komponen kurikulum yaitu media pembelajaran. Media pembelajaran digunakan sebagai alat perangsang dan alat yang disediakan oleh guru untuk mendorong siswa belajar
(Nana Syaodih Sukmadinata, 2009: 208). Pemanfaatan media pembelajaran diharapkan dapat membantu siswa dalam memahami materi pembelajaran yang diberikan oleh guru. Tujuan penggunaan media pembelajaran adalah untuk mempermudah dalam proses pembelajaran dan meningkatkan efisiensi dalam belajar.

Salah satu media pembelajaran cetak adalah modul. Nasution (2003: 205) mendefinisikan "Modul merupakan suatu unit yang lengkap yang berdiri sendiri dan terdiri atas suatu rangkaian kegiatan belajar yang disusun untuk membantu siswa mencapai sejumlah tujuan yang dirumuskan secara khusus dan jelas". Selain sebagai media modul juga berfungsi sebagai bahan ajar. Menurut Abdul Majid (2008:173), "bahan ajar adalah segala bahan yang digunakan untuk membantu guru/intstruktor dalam melaksanakan kegiatan belajar mengajar bisa berupa bahan tertulis maupun bahan tidak tertulis". PP Nomor 19 Tahun 2005 Pasal 20 menyatakan bahwa pendidik diharapkan mengembangkan materi pembelajaran. Pengaturan ini dipertegas malalui Permendiknas Nomor 41 Tahun 2007 tentang Standar Proses yang berbunyi "Perencanaan proses pembe-lajaran mensyaratkan pendidik untuk mengembangkan rencana pelaksanaan pembelajaran (RPP)". Salah satu komponen RPP adalah materi ajar. Dengan demikian, pendidik harus mengembangkan materi ajar atau bahan ajar sebagai salah satu sumber belajar.

Berdasarkan penjelasan di atas, penggunaan modul dalam pembelajaran Akuntansi diharapkan dapat membantu dalam proses belajar mengajar, membantu siswa dalam memahami materi pembelajaran dan mengaplikasikannya dalam mengerjakan soal Akuntansi serta pembelajaran dapat berlangsung dengan efektif dan efisien. Penggunaan modul dalam pembelajaran siswa diharapkan dapat mengembangkan materi 
pembelajaran berdasarkan intruksi yang ada di dalam modul.

Berdasarkan observasi awal yang dilakukan tanggal 9 November 2013 pada kelas X Akuntansi 1 SMK YAPEMDA 1 Sleman dengan jumlah siswa sebanyak 19 siswa menunjukkan adanya beberapa permasalahan dalam proses kegiatan belajar mengajar. Masalah tersebut di antaranya guru yang masih menggunakan model konvensional yaitu ceramah dan pemberian tugas membuat siswa belum dapat mengembangkan kemampuan berpikirnya sendiri dan siswa cenderung masih pasif serta membuat aktivitas belajar siswa rendah saat pembelajaran berlangsung. Saat pembelajaran berlangsung hanya 5 siswa atau 26,32\% siswa yang berinteraksi aktif dengan guru saat guru memberikan penjelasan. Sebanyak 8 siswa atau $42,11 \%$ siswa lebih senang bekerja mandiri dari pada bekerja secara kelompok, dan hanya 4 siswa atau 21,05\% siswa yang aktif berdiskusi dengan teman maupun guru saat mengerjakan soal, sisanya sebanyak 7 siswa atau $36,84 \%$ siswa hanya diam dan menunggu jawaban yang ditulis guru di papan tulis. Saat mengerjakan soal sebanyak 7 siswa atau $36,84 \%$ dapat menyelesaikan soal dengan cepat dan 3 siswa atau 15,79\% mencontek pekerjaan temannya. Perlu adanya perbaikan yang dapat meningkatkan kualitas proses pembelajaran di kelas $\mathrm{X}$ Akuntansi SMK YAPEMDA 1 Sleman sehingga proses pembelajaran dapat berlangsung sesuai yang diharapkan.

Berdasarkan uraian latar belakang masalah tersebut, maka peneliti bermaksud untuk melihat pengaruh pembelajaran terstruktur dan pemberian balikan terhadap aktivitas siswa dengan mengambil judul "Peningkatan Aktivitas Belajar Akuntansi Melalui Model Pembelajaran Kooperatif Tipe Think Pair Share Berbantuan Media Modul Siswa Kelas X Akuntansi 1 SMK YAPEMDA 1 Sleman Tahun Ajaran 2013/2014".

\section{METODE PENELITIAN Desain Penelitian}

Jenis penelitian ini merupakan penelitian tindakan kelas (classroom action research). Penelitian ini akan dilakukan dengan menggunakan dua siklus. Prosedur Penelitian Tindakan Kelas menggunakan model yang dikembangkan Kemmis dan Taggart.

\section{Waktu dan Tempat Penelitian}

Penelitian dilakukan di Kelas $\mathrm{X}$ Akuntansi 1 SMK YAPEMDA 1 Sleman yang beralamat di di Tanjungtirto, Berbah, Sleman Yogyakarta. Penelitian dilakukan meliputi tahap persiapan pada bulan November 2013. Tahap pelaksanaan sampai tahap pelaporan yaitu pada bulan Desember hingga Februari 2013.

\section{Subjek dan Objek Penelitian}

Subjek penelitian ini adalah seluruh siswa kelas $X$ Akuntansi 1 SMK YAPEMDA 1 Sleman tahun ajaran 2013/2014 yang berjumlah 19 siswa, sedangkan objek penelitian ini adalah Peningkatan Aktivitas Belajar Akuntansi melalui Model Pembelajaran Kooperatif Tipe Think Pair Share Berbantuan Media Modul Siswa Kelas X Akuntansi 1 SMK YAPEMDA 1 Sleman Tahun Ajaran 2013/2014.

\section{Prosedur Penelitian}

Penelitian ini direncanakan dalam dua siklus, akan tetapi apabila hasil yang diperoleh belum memenuhi indikator keberhasilan yang telah ditetapkan maka dilanjutkan untuk siklus selanjutnya. Prosedur penelitian setiap siklus terdiri dari empat tahapan, yaitu tahap perencanaan, pelaksanaan, pengamatan dan refleksi.

Pada siklus I tahap perencanaan terdiri dari kegiatan merancang media modul, menyusun RPP, membuat soal latihan. Tahap pelaksanaan tindakan merupakan kegiatan melaksanakan RPP yang telah dirancang di kelas dengan 
menggunakan model pembelajaran kooperatif tipe Think Pair Share. Tahap yang ketiga yaitu tahap pengamatan yang berlangsung bersamaan dengan pelaksanaan tindakan. Pada tahap ini observer mengamati aktivitas belajar akuntansi siswa selama pembelajaran. Tahap terakhir adalah reflesi yang bertujuan untuk mengkaji secara menyeluruh tindakan yang telah dilakukan berdasarkan data yang telah terkumpul, kemudian dilakukan evaluasi guna menyempurnakan tindakan berikutnya.

Prosedur pada siklus II secara garis besar sama dengan prosedur penelitian pada siklus I. Perencanaan siklus II merupakan hasil refleksi pelaksanaan siklus I. Siklus II merupakan perbaikan dari pelaksanaan siklus I, sehingga kekurangan pada siklus I tidak terulang pada siklus II.

\section{Teknik Pengumpulan Data dan Instrumen}

Teknik pengumpulan data pada penelitian ini menggunakan adalah observasi partisipatif, catatan lapangan, angket dan dokumentasi. Pengumpulan data yang berhubungan dengan peningkatan Aktivitas Belajar Akuntansi dengan merapkan model pembelajaran Tipe Think Pair Share berbantuan Media Modul dilakukan dengan observasi partisipatif dan catatan lapangan. Observer mengamati secara langsung jalannya pembelajaran untuk mendapatkan data Aktivitas Belajar Akuntansi. Observer menagamati jalannya pembelajaran dengan berpedoman pada pedoman observasi Aktivitas Belajar Akuntansi yang berisi indikator-indikator Aktivitas Belajar Akuntansi.

Angket dalam penelitian ini digunakan untuk mengumpulkan data respon siswa terhadap penerapan model pembelajaran Tipe Think Pair Share berbantuan Media Modul. Angket yang digunakan adalah angket tertutup yaitu angket yang telah dilengkapi jawaban yang dapat dipilih oleh siswa. Kisi-kisi yang akan dijadikan dasar dalam menyusun angket diambil dari kualitas model pembelajaran dan manfaat Model Pembelajaran Tipe Think Pair Share dan penggunaan Media Modul.

\section{Teknik Analisis Data}

Teknik analisis yang digunakan dalam penelitian ini adalah analisis data kuantitatif dan kualitatif. Teknik analisis data kuantitatif digunakan untuk mengetahui skor Aktivitas Belajar Akuntansi siswa. Langkah-langkah menganalisis data secara kuantitatif adalah sebagai berikut:

a. Menentukan kriteria pemberian skor terhadap masing-masing indikator.

b. Menjumlahkan skor untuk setiap kegiatan aktivitas belajar.

c. Menghitung skor aktivitas belajar dengan rumus,

$\%=\frac{\text { Skor Aktivitas Belajar Akuntansi }}{\text { Skor Maksimum }} \times 100 \%$

(Sugiyono, $2010:$ 144)

Teknik analisis data kualitatif terdiri dari tiga langkah. Pertama, mereduksi data maksudnya merangkum, memilih hal-hal yang pokok, memfokuskan pada hal yang penting dan membuang yang tidak perlu. Kedua, menyajikan data merupakan penyusunan informasi secara sistematik dari hasil reduksi data, dimulai dari perencanaan, pelaksanaan tindakan observasi dan refleksi sehingga akan mudah dipahami. Tahap terakhir adalah verifikasi atau penarikan kesimpulan.

\section{Indikator Keberhasilan}

Kriteria keberhasilan tindakan adalah apabila setelah penerapan Model Pembelajaran Tipe Think Pair Share Berbantuan Media Modul, terjadi peningkatan Aktivitas Belajar Akuntansi. Pembelajaran dapat dikatakan berhasil dan berkualitas jika seluruhnya atau sebagian besar $75 \%$ siswa terlibat secara aktif baik fisik maupun mental (Mulyasa, 2010: 218). 


\section{HASIL PENELITIAN DAN PEMBAHASAN}

Hasil penelitian yang diperoleh dari siklus I belum mencapai kriteria keberhasilan tindakan. Rata-rata Aktivitas Belajar Akuntansi siswa pada siklus I hanya mencapai $74,17 \%$. Pada siklus I hanya 4 indikator dari 10 indikator yang mencapai kriteria keberhasilan mengeksplorasi kemampuannya sendiri $(77,78 \%)$, memperhatikan penjelasan pasangan lain atau guru $(83,33 \%)$, menjawab pertanyaan guru atau teman $(75,00 \%)$ dan bersemangat dalam mengikuti pembelajaran $(86,11 \%)$. Selain itu pelaksanaan pembelajaran pada siklus I juga belum sistematis dan terorganisir dengan baik. Hal tersebut disebabkan oleh beberapa hal seperti siswa belum terbiasa dengan model pembelajaran baru sehingga sering terjadi misscomunication antara guru, siswa dan peneliti sehingga Aktivitas Belajar Akuntansi siswa pada siklus I belum tercapai secara optimal.

Berdasarkan hasil tersebut, maka pada siklus II perlu dilakukan perbaikan agar Aktivitas Belajar Akuntansi siswa kelas X Akuntansi 1 dapat mencapai kriteria yang telah ditentukan. Perbaikan yang dilakukan pada siklus II yaitu pembelajaran dirancang dengan lebih teratur dan instruksi yang jelas, soal diskusi yang lebih bervariasi dengan tingkat kesulitan yang berbeda dengan siklus I sehingga proses diskusi akan lebih tercipta. Terbukti adanya peningkatan sebesar $10,57 \%$ yaitu menjadi $84,74 \%$ pada siklus II dan semua indikator telah mencapai lebih dari $75 \%$. Untuk lebih jelasnya, berikut ini disajikan data perbandingan skor Aktivitas Belajar Akuntansi siklus I dan siklus II :
Tabel 1. Perbandingan Peningkatan Aktivitas Belajar Akuntansi Siswa

\begin{tabular}{|c|c|c|c|c|}
\hline \multirow[b]{2}{*}{ No } & \multirow[b]{2}{*}{ Indikator } & \multicolumn{2}{|c|}{ Skor } & \multirow[b]{2}{*}{$\begin{array}{c}\text { Peningka } \\
- \text { an }(\%)\end{array}$} \\
\hline & & \begin{tabular}{|c|} 
Siklus \\
I (\%)
\end{tabular} & \begin{tabular}{|l|} 
Siklus \\
II (\%)
\end{tabular} & \\
\hline 1 & $\begin{array}{l}\text { Mengeksplorasi } \\
\text { kemampuannya } \\
\text { sendiri (think). }\end{array}$ & 77,78 & 84,21 & 6,43 \\
\hline 2 & $\begin{array}{l}\text { Memperhatikan } \\
\text { penjelasan } \\
\text { pasangan lain } \\
\text { atau guru. }\end{array}$ & 83,33 & 92,11 & 8,77 \\
\hline 3 & $\begin{array}{l}\text { Menyampaikan } \\
\text { hasil diskusi } \\
\text { kelompoknya } \\
\text { (share). }\end{array}$ & 69,44 & 78,95 & 9,50 \\
\hline 4 & $\begin{array}{l}\text { Mengajukan } \\
\text { pertanyaan atau } \\
\text { pendapat kepada } \\
\text { guru atau teman. }\end{array}$ & 72,22 & 92,11 & 19,88 \\
\hline 5 & $\begin{array}{l}\text { Menjawab } \\
\text { pertanyaan guru } \\
\text { atau teman. }\end{array}$ & 75,00 & 89,47 & 14,47 \\
\hline 6 & \begin{tabular}{l}
\multicolumn{2}{l}{ Mendengarkan } \\
penjelasan guru \\
atau \\
pasangannya \\
(pair) dan \\
kelompok lain \\
(share).
\end{tabular} & 72,22 & 76,32 & 4,09 \\
\hline 7 & $\begin{array}{l}\text { Menyelesaikan } \\
\text { tugas dengan } \\
\text { pasangannnya. }\end{array}$ & 66,67 & 84,21 & 17,54 \\
\hline 8 & $\begin{array}{ll}\text { Siswa mencatat } \\
\text { materi yang } \\
\text { dipelajari. }\end{array}$ & 66,67 & 81,58 & 14,91 \\
\hline 9 & $\begin{array}{l}\text { Melakukan } \\
\text { diskusi dengan } \\
\text { pasangannya } \\
\text { (pair). }\end{array}$ & 72,22 & 76,32 & 4,09 \\
\hline 10 & $\begin{array}{l}\text { Bersemangat } \\
\text { dalam mengikuti } \\
\text { pembelajaran. }\end{array}$ & 86,11 & 94,74 & 8,63 \\
\hline & $\begin{array}{l}\text { ta-rata Aktivitas } \\
\text { lajar Akuntansi }\end{array}$ & 74,17 & 84,74 & 10,57 \\
\hline
\end{tabular}

Perbandingan skor Aktivitas Belajar Akuntansi per indikator untuk siklus I dan siklus II dapat disajikan pada grafik berikut ini: 


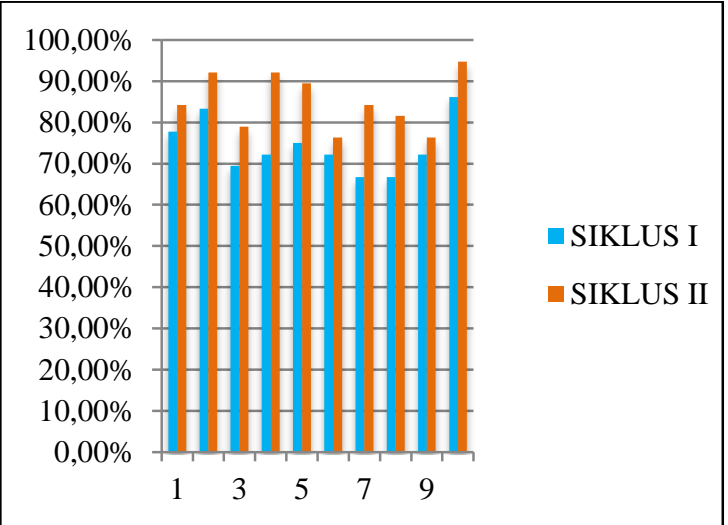

Gambar 1. Peningkatan Setiap Indikator Aktivitas Belajar Akuntansi

Sedangkan data yang diperoleh dari angket respon siswa menunjukan adanya respon positif terhadap penerapan Model Pembelajaran Kooperatif Tipe Think Pair Share Berbantuan Media Modul, hal tersebut ditunjukan dengan rata-rata skor respon siswa mencapai $77,18 \%$ pada siklus I dan meningkat $2,44 \%$ menjadi $79,62 \%$. Data angket respon siswa terhadap Model Pembelajaran Kooperatif Tipe Think Pair Share berbantuan Media Modul pada sikus I dan II dapat dilihat sebagai berikut :

Tabel 2. Respon Siswa terhadap Penerapan Model Pembelajaran Tipe TPS Berbantuan Media Modul

\begin{tabular}{|c|c|c|c|}
\hline Indikator & $\begin{array}{c}\text { Siklus I } \\
(\mathbf{\%})\end{array}$ & $\begin{array}{c}\text { Siklus II } \\
(\mathbf{\%})\end{array}$ & $\begin{array}{c}\text { Peningkat- } \\
\text { an }(\boldsymbol{\%})\end{array}$ \\
\hline 1 & 70.72 & 71.05 & 0.33 \\
\hline 2 & 82.89 & 87.28 & 4.39 \\
\hline 3 & 84.65 & 82.02 & -2.63 \\
\hline 4 & 65.79 & 69.30 & 3.51 \\
\hline 5 & 74.12 & 80.26 & 6.14 \\
\hline 6 & 80.26 & 83.55 & 3.29 \\
\hline 7 & 81.58 & 88.16 & 6.58 \\
\hline 8 & 78.51 & 79.39 & 0.88 \\
\hline 9 & 77.63 & 81.14 & 3.51 \\
\hline 10 & 76.97 & 78.29 & 1.32 \\
\hline 11 & 78.07 & 78.07 & 0.00 \\
\hline 12 & 75.00 & 76.97 & 1.97 \\
\hline Respon & $\mathbf{7 7 . 1 8}$ & $\mathbf{7 9 . 6 2}$ & $\mathbf{2 . 4 4}$ \\
\hline
\end{tabular}

Respon siswa kelas X SMK YAPEMDA 1 Sleman terhadap penerapan Model Pembelajaran Kooperatif Tipe Think Pair Share Berbantuan Media Modul dapat dilihat pada grafik berikut ini:

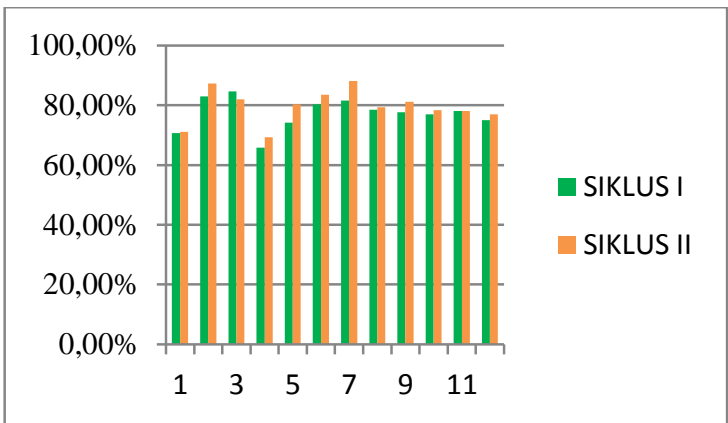

Gambar 2. Peningkatan Indikator Angket Respon Siswa terhadap Penerapan Model Pembelajaran Tipe Think Pair Share Berbantuan Media Modul

Hasil angket respon siswa kelas $\mathrm{X}$ Akuntansi 1 terhadap penerapan Model Pembelajaran Tipe Think Pair Share Berbantuan Media Modul menunjukan ada 1 indikator respon yang mengalami penurunan yaitu indikator menyelesaikan tugas individu saat penerapan model pembelajaran Tipe Think Pair Share yaitu pada siklus I mendapat respon sebesar $84,65 \%$ menjadi $82,02 \%$ pada siklus II. Pada indikator nomor 11 yaitu indikator respon siswa terhadap penggunaan modul pada siklus I dan II tidak mengalami kenaikan maupun penurunan atau tetap yaitu 78,07\%. Walaupun demikian indikator tersebut masih merupakan respon positif sehingga hasil angket menunjukan 12 indikator angket respon siswa mendapatkan respon positif dari siswa kelas X Akuntansi 1.

\section{SIMPULAN DAN SARAN Simpulan}

Berdasarkan hasil penelitian dan pembahasan pada bab IV dapat disimpulkan bahwa penerapan Model Pembelajaran Tipe Think Pair Share 
Berbatu Media Modul dapat meningkatkan Aktivitas Belajar Akuntansi pada Kompetensi Dasar Membuat siswa kelas X Akuntansi 1 SMK YAPEMDA 1 Sleman tahun ajaran 2013/2014. Hal tersebut ditunjukan dengan adanya peningkatan persentase skor Aktivitas Belajar Akuntansi yang merupakan hasil dari pengamatan dengan menggunakan lembar observasi yaitu $74,17 \%$ pada siklus I dan meningkat sebesar $10,83 \%$ sehingga menjadi $85,00 \%$ pada siklus II. Selain itu setiap indikator Aktivitas Belajar Akuntansi juga mengalami peningakatan.

Selain dapat meningkatkan Aktivitas

Belajar Akuntansi siswa, penerapan Model Pembelajaran Kooperatif Tipe Think Pair Share Berbantuan Media Modul juga menunjukan respon yang positif dari siswa kelas X Akuntansi 1 SMK YAPEMDA 1 Sleman Tahun Ajaran 2013/2014, baik dilihat secara keseluruhan maupun dilihat dari setiap indikator baik pada siklus I maupun siklus II.

\section{Saran}

1. Bagi Guru

Guru sebaiknya dapat menerapkan berbagai macam variasi model pembelajaran untuk menciptakan proses pembelajaran yang menyenangkan sehingga mampu mendorong siswa untuk melakukan aktivitas belajar akuntansi yang lebih optimal. Salah satu model pembelajaran yang dapat digunakan adalah Model Pembelajaran Kooperatif Tipe Think Pair Share untuk mengatasi masalah aktivitas belajar.

Terkait penerapan Kurikulum 2013 guru harus mempersiapkan diri. Guru dapat mengembangkan kemampuannya dengan mengikuti seminar, pelatihan serta dengan melakukan penelitian di kelas, sehingga guru lebih siap dalam menerapkan Kurikulum 2013.

2. Bagi Siswa
Siswa diharapkan memiliki andil yang besar dalam proses pembelajaran dengan ikut berperan aktif selama proses pembelajaran, sehingga siswa harus meningkatkan aktivitas belajar demi tercapainya tujuan pembelajaran.

3. Bagi Penelitian Selanjutnya

a. Peneliti selanjutnya diharapkan lebih teliti dan objektif dalam melakukan pengamatan.

b. Peneliti selanjutnya dapat memperbaiki indikator yang telah disusun agar dapat menunjukan peningkatan aktivitas belajar akuntansi secara keseluruhan.

c. Peneliti selanjutnya dapat menerapkan model pembelajaran yang terintegrasi dengan pendidikan karakter dan kegiatan ko-kurikuler seperti yang tertera pada Peraturan Menteri Pendidikan dan Kebudayaan yang mengatur tentang penerapan Kurikulum 2013.

\section{DAFTAR PUSTAKA}

Abdul Majid. (2008). Perencanaan Pembelajaran Mengembangkan Standar Kompetensi Guru. Bandung: PT. Remaja Rosdakarya.

Arif Rohman.(2009). Memahami Pendidikan \& Ilmu Pendidikan. Yogyakarta: Laksbang Mediatama.

Etin Solihatin dan Raharjo. (2007). Cooperative Learning Analisis Model Pembelajaran IPS. Jakarta: PT Bumi Aksara.

Muhibbin Syah. (2010). Psikologi Belajar. Jakarta: PT. Raja Grafindo Persada.

Mulyasa.(2010). Menjadi Guru Profesional Menciptakan Pembelajaran Kreatif \& Menyenangkan. Bandung: PT Remaja Rosdakarya. 
Nana Syaodih Sukmadinata. (2009). Metode Penelitian Pendidikan. Bandung: PT Remaja Rosdakarya.

Slavin, Robert E. (2009). Cooperative Learning Teori, Riset, dan Praktik. Bandung: Nusa Media.

S. Nasution. (2011). Berbagai Pendekatan dalam Belajar dan Mengajar. Jakarta: Bumi Aksara.

Sugiyono.(2010). Metode Penelitian Pendidikan Pendekatan Kuantitatif, Kualitatif dan $R \& D$. Bandung: Alfabeta.

Suharsimi Arikunto, Suhardjono dan Supardi. (2006). Penelitian Tindakan Kelas. Jakarta: Bumi Aksara.

Wina Sanjaya. (2012). Strategi Pembelajaran Berorientasi Standar Proses Pendidikan. Jakarta: Kencana. 